\title{
Urban Mythologies and Urbane Islam: Refining the Past and Present in Colonial-Era Lucknow
}

Justin Jones

\section{OpenEdition}

\section{Journals}

\section{Electronic version}

URL: http://journals.openedition.org/samaj/3943

DOI: $10.4000 /$ samaj.3943

ISSN: $1960-6060$

\section{Publisher}

Association pour la recherche sur l'Asie du Sud (ARAS)

\section{Electronic reference}

Justin Jones, «Urban Mythologies and Urbane Islam: Refining the Past and Present in Colonial-Era Lucknow », South Asia Multidisciplinary Academic Journal [Online], 11 | 2015, Online since 15 July 2015, connection on 06 May 2019. URL : http://journals.openedition.org/samaj/3943 ; DOI : 10.4000/ samaj.3943

This text was automatically generated on 6 May 2019.

\section{$(1) \Theta \Theta$}

This work is licensed under a Creative Commons Attribution-NonCommercial-NoDerivatives 4.0 International License. 


\title{
Urban Mythologies and Urbane Islam: Refining the Past and Present in Colonial-Era Lucknow
}

\author{
Justin Jones
}

\section{Writing the Lucknowi tehzib: urban myths and urban history}

1 If any single work has served to cement the impressions of cultural sophistication associated with Lucknow, it is Hindūstān mēn Mashriqī Tamaddun kā Akhirī Namūna ya'ni Guzushta Luckna'u, ('Lucknow: the Last Phase of an Oriental Culture'), by the Lucknowi novelist and essayist 'Abdul Halim Sharar (1860-1920). ${ }^{1}$ In introductory remarks imbued with heavy affection, Sharar evoked the court of Awadh, and the urban capital of its heyday from 1775 until 1856, as 'the last example of eastern refinement and culture ( mashriqi tehzib-va-tamaddun) in India.' He continues:

We still have memories and present examples of several other courts, but the court in which the old culture and lifestyle reached its culmination was this court, which reached such heights and then, suddenly and sadly, vanished so fast... the place in which this court was established had a greater distinction and importance than any in India. (Sharar 2000 [1914-1920]: 41)

2 The text then describes many of the city's lavish cultures and fashions, ruminating upon the particulars of its costumes, calligraphy, gastronomy, cock-fighting, kite-flying, poetry recitation and etiquette, among many others. Sharar depicts a unique and sophisticated Islamicate ${ }^{2}$ civic culture which, as well as being a pinnacle of Indo-Muslim cultural achievement, was also one of successful integration, amalgamating artistic contributions from across South and West Asia, and facilitating engagement from both Muslim and Hindu populations.

3 Accessible, informative and translated into several languages, Sharar's portrait has heavily influenced modern perceptions of Nawabi Lucknow; yet, this work was hardly a 
first-hand account. First published in 1914-1920 as a series of articles in the Urdu periodical Dil-Gudaz, this was a retrospective evocation of the city's history, penned by an author who had not lived during the era described, and reconstructed from oral testimonies and the recovery of local mythologies. Sharar's essays on his city, then, need to be taken not as historical fact, but as projections of history influenced by his contemporary concerns and the background against which he wrote. In particular, his writings offer a key example of the nostalgia felt by many of north India's Muslim nobility for past glories. Studies of the remembrance of history by Muslim intellectuals in colonial India have often emphasised their sense of loss, crisis and humiliation at the recent ebb of Muslim power in the subcontinent (e.g. Hasan 2007a, Zaidi 2009); however, this lament at Muslim decline was in practice often tempered in Urdu literatures of the period with an active and slightly contradictory romanticisation of bygone achievements. Like Syed Ahmad Khan's evocations of old Delhi, Altaf Husain Hali's elegy for Abbasid Baghdad or Muhammad Iqbal's verse on Cordoba (Khan 1861, Hali 1998 [1879], Iqbal 1993 [1932]), Sharar's account of this Muslim city revealed a longing for its historic splendour and luxuries, even as he simultaneously scorned its decadence.

Sharar's glamorous, quixotic evocation of Nawabi Lucknow was hardly the only one to be penned during this period. Mirza Muhammad Hadi Ruswa's tale of the courtesan Umrā'ō Jān Ādā (Ruswa 1993 [1899]) and Munshi Premchand's legendary Hindi short story Shātranj $k \bar{e}$ Khilāri ('The Chess Players': Premchand 2007 [1924]) are just two fictional accounts dating from roughly the same moment around the early 20th century that shared Sharar's alternation between affection for and scathing criticism of his urban setting. Indeed, Premchand's depiction of the city in the final years of the Nawab's reign was especially evocative, as well as proving that this perception of the city was confined neither to Muslim authors nor to Lucknowi residents:

All Lucknow was steeped in the pursuit of luxury... while some favoured soirees with music and dancing girls, others dedicated themselves to intoxication, to opium. In every department of existence, entertainment and pleasure reigned supreme. Whether in the administration, or in the field of literature, in the arts as in commerce, in everyday living itself, indulgence had become the norm. Employees of the state dedicated themselves to the pleasures of the flesh, poets sang of love and of the pangs of separation, craftsmen turned out fine embroidered fabrics, tradesmen provided cosmetic refinements, perfumes and rare unguents. (Premchand 2007 [1924]: 53)

While Sharar, Ruswa and Premchand's works remain perhaps the most iconic, they were hardly the only such portraits of old Lucknow to be published within this same quartercentury. Many other tracts emerged thanks to the city's status as home to major publishing houses like Nawal Kishore Press (Stark 2007), as well as an emerging public sphere that voraciously consumed ephemeral and serialised publications (Perkins 2013). Among these, Najmul-Ghani Rampuri's encyclopaedic chronicle Tārikh-i-Awadh was an empirically rich account of the intrigues and dynastical conspiracies within the Awadhi court, reflecting new tastes for authoritative historiography in Urdu literature (Rampuri 1919). Other texts catalogued the so-called fashions (wa'zdaran) of the Nawabi city's courtly elite, from dress to dining, in a style that smacked of colonial ethnographies as much as Sharar's historical reflections (Lucknowi 1912). Yet others, influenced by the Urdu genre of advice literature that marked the period, sought to instruct readers on embodying their city's cultural ethos in their daily lives. One such volume, describing itself as a 'goldmine of refinement (ma'adin-i-tehzib) for young Hindustani gentlemen', outlined the etiquette supposedly characteristic of Lucknow, including personal qualities 
like honesty and integrity (rast-guftari, diyanat), the strictures of household conduct ( tadbir-i-manzil) and the proper protocols for entertaining, corresponding and conversing (Husain 1900).

6 Of course, much academic work has often made this utopian ethos ascribed to old Lucknow hard to fully accept. Historians of pre-colonial Awadh have confirmed the existence of deep courtly clientelism within state structures and recurrent social instability in the city's rural hinterlands (Fisher 1997, Alam 1997), combined with a series of religious conflicts over temples, mosques and Muharram processions triangulated among Shi' is, Sunnis and Hindus alike (Cole 1988: 223-50, Cole 2002: 161-72). Such might well lead us to conclude that Nawabi Lucknow's lauded 'last phase' was in fact one wrought with turbulence and stagnation: indeed, the East India Company annexed it on this pretext. This being the case, it seems fair to argue that the image of a luxuriant, harmonious Lucknow was less a historical reality of the early 19th century, and more a product of a retrospective mythologisation of the city in the early 20th. Moreover, far from being limited to these decades, this romanticised vision of Lucknow has been carried forward even to contemporary times. Urdu and English histories reflective of this wistful character have continued to be penned by the city's resident writers for local consumption (e.g. Husain 1981, Kidwai 1993), while a comparable branding exists beyond the city, whether carried via literature, film, costume or cuisine. Even academia has often taken on this tone: recent scholarship in English has continued to frame Lucknow in terms of the survivals of its past (Graff 1997), to evoke it as a 'city of dreams' bound to memories of fallen grandeur (Llewellyn-Jones 1997), and to extol the celebrated sham-iAwadh along the lines of a later-generation Arabian nights (Oldenburg 2007).

7 While this volume's essays all address the various bearings of history upon contemporary Lucknow, this article seeks to trace this practice of invoking the city's past to an earlier period. It suggests that it was, in fact, in the colonial era, and particularly the early decades of the 20th century, that this distinctive historical mythology of old Lucknow was constructed. While many terms were used to evoke the distinctive cultural life of Lucknow in colonial-era writing (saqafat, adab, wa'zdaran, etc.), no term perhaps encapsulates the period's rebranding of the city's past more than that of tehzib. This 'semantically rich' (Stark 2011: 5) term, often translated as 'refinement', in fact blended together ideas of urbanity, civility, morality, erudition and sophistication. While the term had been used earlier to describe specific cultural accomplishments within the city, ${ }^{3}$ its holistic application to describe the totality of Lucknow's historical culture is something that was consolidated long after the fall of the city to the British rather than beforehand. As C. M. Naim has argued:

It was some time in the second half of the $19^{\text {th }}$ century that the many diverse matters that earlier used to be considered separately under such rubrics as adab ('protocols'), akhlaq ('moral codes'), a'in ('administrative rules or constitution'), rusum ('customs'), riwaj ('local practices'), riwayat ('traditions'), funun ('arts and crafts') and so forth, began to be subsumed within one overarching word, tahzib, whose main function... was to imply and then underscore a link between all of them and a single, and almost autochthonous, past. (Naim 2011: 196)

8 This retrospective articulation of a distinctive Lucknowi tehzib, then, remains key to understanding the mythologisation of the city's history. Seeking to offer a survey of a large body of recent academic historiography on the city, and also engaging a range of predominantly Muslim-authored Urdu publications from the city dating from the period in question, this article explores how this imagined version of Lucknow's historical tehzib 
was produced, disseminated and applied by a number of authors, public figures and organisations in the colonial city. It seeks to show not simply that this refined vision of the city's history was largely a construct of the colonial period, but that this vision was also used as a model for refining various aspects of the city's contemporary public and political life. Significantly, this article's approach of tracing the historical mythology that matured around the city, and charting these myths in terms of the functions that they played for those who transmitted them, differs from many urban histories that have been written for colonial South Asia. As Prashant Kidambi has perceptively noted, studies of associational and political life in colonial India have tended to focus upon the city chiefly as a site of 'practice', namely, a place whose capacities for networking and communication allowed new social and political organisations to arise, and enabled selfstyled public men to exact influence over civic populations. More rarely, he argues, have such studies considered the city as an object of 'thought' or imagination itself (Kidambi 2012: 963). This article's approach, arguing that Lucknow acquired a distinctive urban mythology that could be applied to many contemporary ends, draws closer to the approach of some recent anthropologists who have suggested that cities might be considered to hold their own so-called 'urban charisma'. As these scholars argue, cities might be considered to possess their own certain distinctive "soul' or mythology' that lives through both their physical spaces and their residents, and that links their past and present (Blom-Hansen \& Verkaaik 2009: 5-9). Some recent studies of South Asian cities, particularly some recent works on Mumbai, have explored the idea of their modern mythologisation, showing how ruminations upon a city's glorious past can inspire nostalgia in their residents, or act as idealised imaginaries against more recent traumas (Prakash 2010, Chandavarkar 2009: 121-90). Perhaps, though, few South Asian cities have been so heavily mythologised as Lucknow, a city whose modern stagnation often seems to have further entrenched the myths of its reified past.

Expanding beyond the written portraits of tehzib described above, the article's next section turns to colonial Lucknow's public sphere, exploring the city as a space for the performative recollection of tehzib, and examining why Lucknow's past was so recurrently evoked in the colonial city's associational life. The remainder of this article then assesses how this mythologised Lucknowi tehzib was, in the early 20th century, appropriated and instrumentally harnessed, as a means of addressing contemporary social and political demands. Hence, the article's third section turns to political life in the city, specifically the projection of Lucknow's tehzib into nationalist politics, while the article's final pages address how tehzib was harnessed by many Muslim voices as a basis for fashioning a distinctive Muslim cosmopolitanism in South Asia.

\section{Performing tehzib: old Lucknow in new publics}

Recent decades have seen an abundance of academic interest in the interlocked entities of the relatively elite 'associational culture', and the broader and more Habermasian 'public sphere' of civil participation, as they emerged in colonial India's urban centres. This associational life, comprised of an array of new public groups and societies, socialised an English-educated elite in the liberal ideals of volunteer activism, philanthropy and social and educational progress, and ultimately paved the way for the development of political and nationalist activity among Indian elites by the late 19th century (e.g. Haynes 1991, Watt 2005). Much historiography has argued that, positioning 
themselves as representatives of the Indian population before the state, these organisations were compelled to adopt elements of the language, organisation and procedure of the colonial administration with which they aspired to engage. Their appropriation of an Anglicised vocabulary of aspirations such as 'improvement', 'progress' and 'public good' comprised, as memorably put by Douglas Haynes, a 'conceptual straitjacket' by which these organisations further embedded colonial hegemony in India's associational life (Haynes 1991: 145-6, Chatterjee 1986: 1-17). While this framework has been heavily applied in studies of colonial India's urban public sphere, it has been both implicitly and explicitly critiqued by a number of excellent recent studies of colonial Lucknow (Joshi 2001, Stark 2011, Perkins 2013). Many of these have shown that the array of public associations that emerged in Lucknow did not, like some larger 'All India' organisations, simply appear to emulate colonial deliberative models, but instead often seemed to ground themselves in motifs and symbols drawn from the city's mythologised history. As such, these organisations became major participants in the reproduction of a certain perception of Lucknow's past, while turning Lucknow's public sphere into a space for the performative recollection of the city's tehzib.

Before endeavouring to explain why the city's associational life was often so wilfully evocative of the city's history, it is worth providing a roadmap of the labyrinthine array of literary and reform societies, debating clubs and public service organisations which emerged in the colonial-era city. The earliest significant organisation of this kind was the Anjuman-i-Hind-i-Awadh, a landlord-based group set up in 1861 to petition the government on the loyal ta'luqdari (landholding) interest, which ultimately set a prototype for the emergence of a wider inventory of middle-class and professional associations. The Jalsa-i-Tehzib, founded in 1868 by a number of Hindu and Muslim government officials and journalists, was more deeply rooted among the city's urban literati; it sought to provide a new forum for discussing issues of public significance (Stark 2011). By the 1890s, the more openly political Rifah-i-'Am was active in pressing a particular vision of the 'common good' as was embedded in its own title, making representations before the colonial bureaucracy on this basis. Many other associations existed to represent limited groups bonded by kinship, profession or common interest. Examples included the Anjuman-i-Khandan-i-Shahi, an organisation of the former royal family founded after the death of Wajid 'Ali Shah in 1887. Some groups represented particular professional elites, such as the Anjuman-i-Wuqala (Society of Lawyers) founded in the 1870s (Stark 2011:11), indicating the importance of public organisations in fashioning new middle-class identities bonded by shared aspirations to public participation (Joshi 2001: 1-10, 23-48). Other organisations were more communitarian in focus, among them the All India Shi' a Conference, created amongst one of the city's most influential minority communities in 1907 (Jones 2012: 114-25), and the Indian Kayasthas Association, a caste sabha representing a community with long local history as officials and pensmen of the Nawabi court and British Raj (Bellenoit 2014).

Additionally, a number of predominantly Muslim literary and cultural societies were established in Lucknow from the 1890s onwards to safeguard the city's perceived cultural distinctions; among these were the Da'ira-i-Adabiya, founded by the famed marsiya poet 'Ali Naqi Safi for the discussion of Lucknowi poetry and literatures, and the Anjuman-iMe'yar-i-Adab, which organised musha'iras (poetry galas) resonant of the old city's cultural life (Husain 1981: 262-7). Similar efforts were made by the city's influential bodies of 'ulama (Islamic scholars), who sought to preserve the city's parallel stature as a 
centre of Islamic learning. In 1910, a number of the city's Shi'i 'ulama established the Anjuman-i-Yadgar-i-'Ulama, an organisation dedicated even by name to the memorialisation of earlier generations of scholars via the commissioning of biographies and republication of their works (Hindi 2010 [1918]: 15-9). Several organisations also sprung up pledging the reparation or beautification of the city's Nawabi architecture, including the Anjuman Mushir-i-Iman, established in 1912 to restore the city's antiquated mosques and imambaras (Jones 2012: 76). Such organisations contributed as much as any printed works to perpetuating public awareness of Lucknow's past and venerating its distinctions.

In many ways Lucknow's associations did reflect broader trends identified in studies of colonial India's urban public sphere: most leading members of these organisations, many of whom were old nobility, landed gentry, lawyers or government officials, were tied to the colonial bureaucracy by careers or interest, and used these new forums to seek public and political influence. Yet, if we examine Lucknow's organisations not as state-facing entities but in terms of the languages they applied and the performances they enacted, we see a very different relationship with the city, construed around an invocation of Nawabi Lucknow's fashions and manners. For instance, one frequent reference made by these organisations to the city's past was an often striking preservation of an IndoMuslim linguistic idiom. It has long been suggested that many organisations seeking public influence in colonial India adopted an Anglicised vocabulary (Conference, Society, Resolution, Statutes, Presidents, etc.) and procedural style. In reality, however, comparatively few of these Lucknowi organisations took on such Anglicised terminologies. The Jalsa-i-Tehzib, for instance, in contrast to many Muslim-led sociocultural organisations of the same generation, such as Syed Ahmad Khan's Scientific Society or Ameer Ali's Central Muhammadan Association, avoided such linguistic acculturation. Instead, grounding itself even by name in tehzib, it could be seen as maintaining foundations in the city's history and a linguistic and cultural distance from the colonial public societies upon which, in other ways, it was apparently modelled. Likewise the Rifah-i-'Am, whose name could be read simply as a vernacular translation of the liberal notion of 'public good' (Haynes 1991:145), could alternatively be interpreted as evoking India's Islamicate past: it is noteworthy that the same phrase was being used in Urdu historical writings of the same period to describe the progress bestowed upon India by Muslim rulers, ${ }^{4}$ while the concept also invoked Islamic legal concepts of common benefit and social concern (maslaha), that were circulating in transnational scholarly debates of the era (Opwis 2005: 182-4, 197-201).

As well as their designations, much of the imagery and ritual protocol adopted by these organisations looked not to European cultures of public volunteerism, but to old Lucknow. As we can see from proceedings (ru'idad) compiled by these organisations, their flamboyant, Perso-Urdu rhetoric and performative style remained heavily reminiscent of old Lucknow. The Jalsa-i-Tehzib, for instance, conducted 'rigid ceremonial' audiences with 'elaborate etiquette', all later documented in writing within a 'highly formulaic Persianate idiom' (Stark 2011:9): records note the taking out of numerous antique formalities (adab-va-taslimat) and the making of offerings (nazr) to the session chair (Stark 2011:9). Likewise, the Rifah-i-'Am and Shi'a Conference took on imagery dimly reminiscent of the Nawabi court: their sessions were described as darbar, with the presidential chair as a throne (takht); they paid great attention to the Persianate terms of rank and nobility held by their speakers; and they addressed their delegates with such 
exalted and lofty titles as Nawab, Janoob, buzurg and huzoor (Jones 2012: 125). Even the entirety of Lucknow's public sphere itself could be construed in Nawabi imagery: Sharar himself sometimes construed the city's 'public' as a darbar: an acknowledgement of the importance of public opinion, but equally an allusion to the city's courtly past (Perkins 2011: 13).

As such, the mythologies of old Lucknow were frequently invoked in the language, procedure and performance of the colonial city's associational life. Moreover, while some associations recalled Lucknow's tehzib more explicitly than others, the consistency of its evocation is striking. Many traditional methodologies applied to urban history in South Asia, particularly the 'Cambridge school' approach of various studies of the 1970s-80s, tended to conceive urban society as factional and prone to organising along lines of class, community and 'interest groups' (Bayly 1975: 271-83); quite in contrast, the evocation of old Lucknow seemed to be a perhaps surprisingly collective phenomenon across the city's associational life. While some studies have identified the Lucknowi public sphere with an emerging middle-class, and therefore argued that it carried an 'anti-aristocratic edge' that aspired to 'marginalise the older elites of the city' (Joshi 2001: 23-48), it is important to recognise how extensively even middle-class associations made symbolic nods towards the Lucknowi tehzib, perhaps seeking to draw from historical as well as colonial models of urban respectability.

It is perhaps in this sense that colonial Lucknow's public sphere can only be seen as making a partial, 'fractured' or 'hybridised' transition towards a colonial modernity (Joshi 2001). While the city's public associations did address the government bureaucracy on the basis of liberal appeals, a focus on the linguistic and performative elements of Lucknow's civic life shows a contrary effort to invoke remnants from the city's precolonial past. This apparent ambivalence, between discussing contemporary questions on the one hand and evoking old tehzib on the other, meant that the city's public figures found themselves sometimes attempting to communicate through multiple meters simultaneously. One might take, for instance, the example of the Awadhi taluqdar, Yusuf Husain Khan. In the 1910s, he was a well-known contributor to the English-language press , writing on liberal causes such as constitutional reform, Muslim-Hindu unity and progressive Muslim education (Robinson 1974:378). However, he simultaneously kickstarted a debate with a newspaper article simply entitled 'Awadh', in which he called for an agitation for an independent 'small state [to] be formed in the vicinity of Lucknow' and returned to the former royal family. ${ }^{5}$ The article, unsurprisingly, sparked heavy debate across the vernacular press about the possibility, or indeed wisdom, of reinstating Lucknow as rehabilitated Nawabi capital. ${ }^{6}$ But it also encapsulates the frequent thinness of the boundaries between formal political discussion and fantastical political thought that fetishised past glories.

Several reasons might be posited for the retention of symbolism drawn from old Lucknow in the modern public sphere. One, of course, is that much of the public sphere remained the preserve of established elites, for whom the constant invocation of established imagery of social authority and procedures associated with nobility contained clear personal advantages. Alternatively, we may speculate that this ongoing performance of history could provide sanctuary from a present that may, in various ways, have been deemed hostile. The realities of colonialism in the city, which had seen the infliction of harsh reprisals by the Raj on post-Rebellion Lucknow (Oldenburg 1984), followed by a half-century of population decline and economic stagnancy (Thomas 1982), may have 
compelled a turn to perceptions of past wealth and luxury. Alongside these tribulations, it could also be that ruminations on old Lucknow's decadent pleasures and leisurely living offered light relief from a fraught contemporary context of socio-religious reform, in which various Hindu and Muslim organisations alike placed a new emphasis upon austere behaviour and so interpreted such activities as obscenities (Gupta 2005). Either way, if the preservation of 'old' lifestyles by the city's old elites, whether landowners, courtly pensioners or courtesans, could comprise one form of 'resistance' (Oldenburg 1997), then perhaps the ongoing public ritualisation of old Awadh could similarly be used as a means of defying these contemporary misfortunes.

Markus Daechsel has spoken of colonial India's urban public sphere as combining two different lives: the 'politics of negotiation', by which Indians participated in formal sociopolitical and constitutional discussions, and the 'politics of self-expression', an articulation of imaginative and often anarchistic ideals that often conjured highly divergent visions for India's future (Daechsel 2005: 18-9). This framework might be applied to colonial Lucknow's often multi-vocal public sphere. With the city's associations engaging the colonial bureaucracy in word while simultaneously invoking the city's past in performance, and with authors like Yusuf Husain Khan reflecting on contemporary constitutional minutiae while also fantasising about the re-imposition of Awadhi monarchs, it perhaps makes sense to think of the city's public sphere as a place of both discussion and imagination. The city did not, as some established frameworks might have it, merely host the public sphere, but also became its subject. Through an ongoing performance of Lucknow's tehzib, the urban public sphere could articulate and sustain the city's charisma, and in the process, could defy colonial modernity at the same time as engaging it.

\section{Politicising tehzib: urban mythologies in nationalist politics}

As noted earlier, one major feature of Lucknow's mythologised tehzib was its perceived ability to cultivate harmony between the city's religious communities. While in reality communal conflagrations occurred both pre-1857 and particularly in the colonial period, the imaginary of an urban peace built upon an ethic of collective geniality among city residents became part of the mythology of old Lucknow's refinement, and distinguished it from the social turbulence characteristic of other towns. Again, Sharar's account of Lucknow's history is one example of this, emphasising the integration of Shi' is, Sunnis and Hindus alike into Awadh's court and culture. He documented at various points the good relations between Shi'is and Sunnis, quoting King Wajid 'Ali Shah as saying 'of my two eyes, one is Shia and one is Sunni'; he also made frequent nods to Hindu-Muslim cultural exchange, for instance in his noting of the same king's composition of rahas (Hindu operas) and his theatrical performances of the role of Krishna in these events (Sharar 1975 [1920]: 74-5, 84-5).

With the so-called 'Hindu-Muslim question' becoming a dominant issue in early 20th century north India's politics, Indian public figures were forced to adopt one of several strategies to address it. Some, echoing colonial rhetoric and principles, adopted notions of balances and safeguards (whether legal, educational or political) to protect the needs of different religious communities, while others called upon an ideal of 'Indianness' that 
overrode religious particulars. Another, less-noted approach was to look to local histories of inter-communal harmony as providing a prototype for Hindu-Muslim cooperation on a contemporary national canvas. At important junctures in the colonial period, it seems that Lucknow's mythologised tehzib thus assumed more explicitly political applications, with the city's harmonious past being referenced as a model for fostering collective concord and remedying communal controversies. Indeed, even Sharar's ruminations on old Lucknow contained within them what Perkins has identified as a 'politics of nostalgia', an attempt to extract contemporary messages from Lucknow's illustrious past. Sharar's aim, he argues, was 'not to give a balanced and accurate historical picture of Lucknow', but to use this vision of a 'utopian past to foster the creation of a contemporary climate free of sectarian tensions' (Perkins 2011: 338, also 296-310, 316-41).

The clearest means of examining the use of tehzib as an ethic of political accommodation is to turn to political activity in Lucknow at two key junctures at which the city's own distinctive culture was appropriated as a model for harnessing a composite nationalist politics. The first was the holding of concurrent sessions of the Indian National Congress and All India Muslim League in the city, in December 1916. With a conglomerate of nationally important politicians present in the city, including Bal Gangadhar Tilak, Annie Besant, both Motilal and Jawaharlal Nehru and Muhammad Ali Jinnah, these meetings gave rise to the so-called 'Lucknow Pact', an agreement between the organisations on mutual aims and strategy which directed nationalist activity for several years. This was, of course, a coup for the city itself: not only had 'the name of the city [...] been given to one of the great icons of Indian nationalism', but it foreshadowed several years in which, thanks to the influence of the Pact and the prominence of the city in the Khilafat movement, Lucknow's national political profile was at its highest (Robinson 1997: 208-11).

Scholarship on the Lucknow Pact has typically focused upon its political significance, especially its forging of unity between Congress and the Muslim League, or between Moderate and Extremist factions within Congress itself (e.g. Owen 1972). Much less has been said about the Lucknow Pact as a symbolic performance. But newspaper accounts and memoirs reveal that the sessions appeared to be branded with a series of Lucknowi motifs and insignia. Sessions were held in the Qaiserbagh Baradari, the archetypal edifice of Lucknow's public sphere, and were opened with recitations of Urdu verse by delegates: an allusion to Lucknowi traditions of poetry reading. Hindu Congressmen attended the Muslim League sessions and vice-versa; in the former case, they made 'offerings' to the session president at his 'throne' in rituals further reminiscent of darbari culture. Many delegates wore embroidered chogas, a form of Islamic noble regalia, rather than the Anglicised dress classic to early nationalists. And perhaps most bizarrely, Tilak had the tyres of his automobile slashed by enthusiasts outside the city to compel him to travel to the sessions by carriage, as was more befitting of the city's tehzib. ${ }^{7}$ Equally significantly, the term often used subsequently to describe the political agreement in the vernacular press was not, as one might normally expect, the transliterated English word 'Pact'; but the more loaded Arabic-Urdu term mu'ahida, indicating 'covenant'. A term of Qur'anic progeny which implied the sense of trust between God and man as well as political treaty (Ebstein 2011), it echoed an Islamicate political language, and the diplomatic terminology of the Ottoman Empire or Qajar Iran, more than anything usually apparent in Indian politics. It equally, moreover, evoked classical Islamic jurisprudence on the notion of 'contract' ('ahd) with zimmis (non-Muslims) living under Muslim rule (March 2009: 53-4), 
hence perhaps alluding to a historic Indo-Islamic precedent for a contemporary political treaty between the two communities.

This example therefore reveals how old Lucknow's memorialised tehzib was cast anew as a distinctive political ethic. With its alleged courteous ethos and its supposed history of cross-confessional cordiality, the city was seemingly appropriated as a fitting backdrop to India's most significant declaration to date of Hindu-Muslim political unity. One might speculate that the proliferation of Lucknowi imagery at these political events owed to the role played by city lawyers and politicians, especially Wazir Hasan and the Rajas of Mahmudabad and Jehangirabad, in organising the sessions, and the dominant presence of local delegates: perhaps by immersing political conventions in the imagery of old Lucknow, it was felt that the city's gracious mannerisms could infuse their sessions' deliberations. In any case, the fact that the city had its name etched upon one of colonial India's most significant statements of cross-community cooperation would serve retrospectively to embed further the city's identification with communal harmony, for both colonial-era politicians and later historians alike.

24 A second episode which illustrates the harnessing of a distinctly Lucknowi idiom for national political purposes relates to events in the city during the Quit India movement of 1942. In this year, Lucknow's influential Shi'i scholar 'Ali Naqi Naqvi, together with a number of the city's Sunni and Hindu lawyers and journalists, organised a so-called 'Husain Day', an event to commemorate the $1300^{\text {th }}$ anniversary of the martyrdom of the Shi'i Imam Husain. 'Ali Naqi was renowned for his evocation of Husain as a universal exemplar, whose central message and struggle for justice were relevant to all religious communities (Jones 2014: 422-29). His was a highly ecumenical perspective on Husain that, in identifying Husain as a figure of cross-confessional relevance, echoed past efforts in pre-1857 Lucknow to use the remembrance of Husain and associated Muharram ceremonials as collective acts to unite the city's communities (Cole 1988: 92-119). While this commemorative event had been fore-planned as a notionally non-political gathering, its occurrence in August 1942, at the heart of the Quit India movement, unexpectedly linked the convention with the nationalist agitation, with Husain being revered as a suitable icon in the universal struggle against oppression. Held like so many public events (including the 1916 Lucknow Pact sessions) in the Qaiserbagh Baradari, this was a distinctly Lucknowi performance in its procedure, its Shi'i subject, its recitals of Lucknowi marsiya poems and its elicitation of participation from across religious communities. Addressing the crowd, 'Ali Naqi remarked on the presence of Muslims, Hindus, Sikhs and others, all gathered together in Lucknow and pledging admiration for the martyred Imam (Husain c. 1943: 41-3): an evocation of the Karbala story imbued with the ethics of harmony and cross-confessional participation particular to Lucknow's tehzib. As in 1916, this particular municipal ethos was projected once again onto the national level as a model for the construction of an ecumenical politics.

These two examples, of the lexicon of symbols applied to the 1916 Lucknow Pact sessions and the use of Imam Husain as model for composite nationalism in 1942, show how an imagined mythology of Lucknow could be appropriated in the service of distinctive political causes, and applied as a symbolic backdrop to key junctures in the nationalist movement. What can we learn from the summoning of symbols drawn from Lucknow's mythologised history as a standard for modern politics? On one level, colonial Lucknow offers a clear example of how new forms of urban associational life could be used to foster communal accord, by inculcating a sense of common orientation and collective history 
shared by residents of particular towns (cf. Varshney 2003). From another angle, the examples may remind us to interpret nationalist thought in India not as a totalising political discourse drawn from liberal Western prototypes, but rather, as something grounded in the histories and symbolic languages of particular precolonial South Asian polities. Invocations of nationality, in other words, could incorporate 'regional patriotisms' that called upon 'modes of thought drawn from the Indian past' (Bayly 2001: 19-21, 98-104), in this case, the courtly civility of Awadh. Either way, this particular application of Lucknow's past indicated a wresting back of claims to cross-confessional political cooperation. In other words, forms of contemporary communal accord were to be grounded not in colonial-style rubrics of tolerance, safeguards and representation, but in old Lucknow's incorporative ethos. This invites us to investigate further these intricate links between the evocation of Lucknow's historic tehzib and modern questions of crosscommunity accommodation.

\section{Tehzib-ul-Islam: Lucknow's Muslim cosmopolitanism}

Lucknow was not, of course, an exclusively 'Muslim' city, and a welcome body of recent work on colonial Lucknow's Hindu publics has shown how vibrant and vocal these were during the colonial period (e.g. Joshi 2001: 96-131). This said, the focus of this article upon a body of primarily Urdu and Muslim-authored portraits invites us to reflect further upon how the city's colonial-era Muslim writers and residents harnessed the city's perceived past as a glorious Islamic centre, in a period seen as so definitional to the construction of communitarian Muslim identities in South Asia. In this section, we consider how Lucknow's tehzib defined the city's status as a Muslim centre; and further, how Lucknow's distinctive history could be applied by Muslim voices to navigate modern questions of pluralism, tolerance and inter-communal accommodation. Lucknow, this section suggests, has at times become a point of reference for such questions relating to the often-evoked 'Muslim predicament' in $20^{\text {th }}$ century South Asia.

It was the idea of tehzib, once again, that best reveals how colonial Lucknow was conceived and conveyed by so many authors and orators as a quintessential Islamic city, even after the traumatic fall of Muslim power. The term of tehzib, of course, was not a purely local concoction specific to Lucknow, but one with long-standing roots in Islamic thought. Elaborated as a notion of ethical refinement by classical-era philosophers including ibn Miskawayh and al-Ghazali (ibn Miskawayh 2002-3, al-Ghazali 1995 [1095-1106]), it was henceforth adopted in various contexts both in and beyond South Asia. In colonial India, the language of tehzib was broadly associated with the Muslim modernist circles clustered around Syed Ahmad Khan, who founded the journal Tehzib-ulAkhlāq in the 1870s (Devji 2007: 72, Stark 2011: 5). These weighty connotations meant that the application of the term to colonial-era Lucknow established the city as a definitive expression of Islamic cultural and ethical refinement, linking its cultural distinctions both to the reformist agendas of contemporaneous South Asian Muslim modernists and also to a wider ethical paradigm with centuries of history across the Islamic world. This argument that Lucknow was construed as a particular urban embodiment of universal Islamic values is supported by the fact that, in the same years as tehzib was being holistically applied to Lucknow's civic culture, it was simultaneously being used increasingly within the city in reference to exclusively 'Islamic' laws and manners: in the 1900s-1920s, several prominent city 'ulama, Shi'i and Sunni alike, compiled major hadith 
commentaries under the title of Tehzib. ${ }^{8}$ This could, of course, indicate the existence of contrasting senses of refinement under the same broad term, but conversely, it could represent an attempt to amalgamate the distinctions of transnational Islamic expertise with Lucknow's distinctive cultural sophistication. For the 'ulama, moreover, the articulation of a tehzib-ul-Islam perhaps allowed their commentaries to carry the hallmark of their city of production, and hence boost their city's (and therefore their own) standing within a wider network of religious learning.

If Lucknow's historical tehzib, therefore, was evoked as one of inherently Islamic character, how did this relate to an urban culture that, as noted above, was widely described as incorporating residents of all religions? Significantly even authors like Sharar, who were keen to document Hindu participation in Lucknow's cultural life, were nevertheless clear that tehzib was insolubly rooted within Islam: only India's Muslim rather than Hindu courts, he argued at one point, 'could be considered refined and cultured' (Sharar 1975 [1920]: 78). Unlike, say, the notion of the ganga-yamni culture which is sometimes used in reference to this stretch of riverine northern India and implies the blending together of Hindu and Muslim cultural influences (Kudaisya 2007), most key accounts of Lucknow's tehzib framed it as a culture that came from within Islam, but which, despite this, was not restricted to an explicitly Muslim collective. This was an authentic Islamicate culture that, due to its great accomplishments and universal relevance, could compel participation from others.

Interestingly, this definition of Lucknow as an epithet of a wider Islamic ethical paradigm in which all could partake compares strongly with a number of recent studies of modern so-called Muslim cosmopolitanism, both for South Asia and beyond. Moving beyond a rubric of interaction between universal/ classical 'religious' and local/ little 'cultural' traditions characteristic of some anthropological works on Islam (e.g. Geertz 1971), these studies have argued that examples of cosmopolitanism were articulated as having their origins within an Islamic code of refinement, rather than through compromise with external elements. One study, for instance, defines Muslim cosmopolitanism as 'a form of public conduct that was shaped by Islamic learning'; it 'cultivated urbane civility as Muslim universalist virtuous conduct' while, despite its cross-confessional transferability, remaining 'deeply rooted in the scriptures' (Alavi 2011: 1, 28). In other words, perhaps we should understand living forms of Muslim cosmopolitanism, including Lucknow's retrospectively mythologised tehzib, not as local cultural systems combining an invariable 'Islam' with regional or non-Muslim elements, but rather, as particular expressions of an Islamic universalism embodied in specific historical and geographical circumstances, and based around shared standards of ethical comportment (cf. Kresse \& Simpson 2007: 26).

This definition of an Islamicate cosmopolitanism in Lucknow rooted in local expressions of civility and refinement, ones derived from Islam but in which those of other religions could participate, has implications for how Lucknow's Muslim authors conceived the city's cultural and confessional pluralism. It helps us to understand why Muslim attempts to evoke cross-community harmony in colonial Lucknow were so often conveyed not in a liberal vocabulary of equality or dialogue between different religions, but through a lexicon of Islamic motifs and symbols. The imageries of cross-confessional coexistence discussed earlier in the article, ranging across darbari protocols, concepts of rifah-i-'am, zhimmi contract, shared reverence for Imam Husain and others, were all drawn from within an Islamic frame of reference. Perhaps echoing other historical Muslim ruling strategies for managing religious diversity across culturally plural Asia (Reid 2009), these 
Lucknowi writings and practices all grounded Lucknow's ethics of co-existence within Islamic understandings of cultural conduct and legal thought. In doing this, they managed to evade the colonial language of majorities and minorities, and abrogated the need for neutral arbitration. This was, furthermore, a striking, locally-formulated urban solution to the Hindu-Muslim question, at a time when national politics was increasingly working through communitarian frames, and when political movements such as Muslim separatism and pan-Islam appeared to be viewing Muslim political destinies in exclusivist terms.

31 As such, in an era which witnessed the growth of communalism in India and frequent debates about Hindu-Muslim relations in public life both beyond and within the city's confines, old Lucknow took on particular resonance for some of its Muslim authors as a model for a pluralist and harmonious society that nevertheless remained embedded in Islamic values. Even since independence, these visions of a historic Lucknowi Muslim cosmopolitanism have been engaged to articulate the place of Muslims within modern India. One might here note arguments put forward by Abu'l Hasan 'Ali Nadwi, former principal of Lucknow's Nadwa't ul-'Ulama madrasa and one of $20^{\text {th }}$ century India's most influential Islamic scholars, who has often been analysed as a key exponent of interreligious dialogue (Sikand 2000:34-44). In his discussions of Islam's interaction with the Indian environment, he spoke of Islam as a 'way of life' and 'code of conduct' that was able historically to permeate India on the grounds of its ethos of morality, simplicity and sincerity (Nadvi 1960: 67-71). While his argument was articulated around Indian Islam more broadly, we can perhaps see in this line of argumentation the influence of his own city's mythologised tehzib, and he indeed cites Lucknow among the centres in which 'the graceful, easy and well-mannered mode of life' drawn from Islam matured and in which 'Indo-Islamic fusion' was most perfected (Nadvi 1960: 75). Even after independence, then, the mythology of old Lucknow's Muslim cosmopolitanism could be called upon as a solution to the contemporary questions of the place of Islam within Indian society, and its contributions to it.

\section{Conclusions}

This article has argued that the frequently invoked idea of Lucknow's tehzib, one that still endures today, was less a historical reality of the early $19^{\text {th }}$ century than it was a particular mythology that was constructed in the early $20^{\text {th }}$. The re-imagination of Lucknow's past, as pursued by writers, public leaders and politicians of the city both in and since the colonial period, has served various purposes at different junctures. In the early 20th century, it could offer retreat from an unsympathetic colonial present, could allow the perpetuation of 'old' lifestyles and structures of authority, and could provide a model for sustaining contemporary urban peace and harmony. Significantly, the city's heavily mythologised cosmopolitanism was also harnessed at important moments to endorse a pluralist national politics, and was also subsequently re-visited as a distinctively Muslim response to questions of cultural and religious pluralism in India.

Lucknow, of course, was not the only South Asian city to be retrospectively mythologised according to later concerns, and the arguments made above may perhaps readily apply elsewhere. To take another former north Indian centre of Muslim power, colonial-era Delhi had its pre-colonial history used in similar ways. The city's Muslim intellectuals comparably lauded the late-Mughal city as a place of sophistication and pleasure, 
glorifying its poetry and courtliness (e.g. Baig, 2010 [1900s]: 51-154), while late-colonial nationalists also evoked memories of Delhi's pre-colonial Hindu-Muslim amity as evidence of the inherent possibilities for inter-communal harmony. ${ }^{9}$ Similar arguments may well be applied to other South Asian cities whose Muslim inhabitants have continued to invoke their pasts, from Lahore to Hyderabad. Nevertheless, the point remains that, both in Lucknow itself and in other settlements and districts elsewhere in former Awadh, the mythology of old Lucknow remained potent as both a lived experience and a political reference point throughout the colonial period. One might also suggest that, by comparison with the enormous resettlements, social upheaval and political reconstruction that took place in cities like Delhi upon India's partition and independence, Lucknow's apparent dormancy and waning of national prominence after 1947 has simply cemented a tendency to read the city in terms of its earlier heyday, explaining why the city's mythologies have endured so powerfully.

Partha Chatterjee has drawn attention to what he describes as a lack of agency by the Indian elite in thinking about the city'. He argues that 'two or three generations of social and political thinkers, scholars and artists, poets and novelists, living and working in the era of nationalism,' considered the city as 'a profane place' riddled with bureaucracy and alienation, and instead 'devoted most of their imaginative energies to the task of producing an idea not of the [...] Indian city, but of a rural India' (Chatterjee 2006: 140-1). It is well-known that many of colonial India's key political thinkers, from Gandhi to Nehru, fetishized Indian ruralism; they evoked a somewhat Orientalist notion of 'village community' as a model for remaking an authentic India, and attempted to mobilise the countryside as a mark of their national legitimacy. ${ }^{10}$ Following such thinkers, scholarship has sometimes itself also served to marginalise the Indian city, framing it as a place of organisational convenience rather than an object of thought. That these mythologies of a collective civic tehzib, so recurrent in nationalist-era Lucknow, could take on so many social and political applications might remind us of the importance of considering the colonial South Asian city as more than a mere space for the conduct of Indian bourgeois associational or political life. By contrast, as this article has illustrated, the city could also function as a thing of imagination: it could possess its own charisma that informed the thoughts of its inhabitants; it could, like the village, acquire its own mythology, and become a focus for the recollection of India's idealised pasts. It is this enormous investment in Lucknow's history, as it first took shape in the colonial era, which perhaps provides the background to the ongoing historical consciousness associated with the city and which, as this volume's essays show, both offers inspiration to and exacts burden upon the city's present.

\section{BIBLIOGRAPHY}

Ahmad, Maqbool (2005 [1920]) Tehzỉb ul-Islām, Lucknow: Nizami Press.

Alam, Muzaffar (1997) 'The Awadh Regime, the Mughals and the Countryside' in Violette Graff (ed.), Lucknow: Memories of a City, Delhi: Oxford University Press, pp. 16-31. 
Alavi, Seema (2011) 'Siddiq Hasan Khan (1832-90) and the creation of a Muslim cosmopolitanism in the $19^{\text {th }}$ century', Journal of the Economic and Social History of the Orient 54, pp.1-38.

All India Shi'a Conference (1908) Rū'ìdād-i-ijlās-i-awal-i-Āl Indiā Shī'a Kānferans, Lucknow: October 1907.

Ambedkar, Bhimrao (1946) Pakistan or the Partition of India, Bombay: Thacker.

Andrews, Charles Freer (2003 [1929]) Zakaullah of Delhi, introduced by Mushirul Hasan and Margrit Pernau, Delhi: Oxford University Press.

Bayly, Christopher A. (1975) The Local Roots of Indian Politics: Allahabad 1880-1920, Oxford: Oxford University Press.

Bayly, Christopher A. (2001) Origins of Nationality in South Asia: Patriotism and Ethical Government in the Making of Modern India, Delhi: Oxford University Press.

Baig, Mirza Farhatullah (2010 [1900s]) The Last Musha'irah of Dehli, translated and introduced by Akhtar Qambar, Delhi: Orient Blackswan.

Bellenoit, Hayden (2014) 'Between Qanungos and Clerks: the Cultural and Service Worlds of Hindustan's Pensmen, c.1750-1850', Modern Asian Studies, 48(4), pp. 872-910.

Blom-Hansen, Thomas \& Verkaaik, Oscar (2009) ‘Urban charisma: On Everyday Mythologies in the City', Critique of Anthropology 29(1), pp. 5-26.

Buruma, Ian \& Margalit, Avishai (2004) Occidentalism: A Short History of Anti-Westernism, London: Atlantic Books.

Chandavarkar, Rajnarayan (2009) History, Culture and the Indian City, Cambridge: Cambridge University Press.

Chatterjee, Partha (1999 [1986]) Nationalist Thought in the Colonial World: A Derivative Discourse?, Delhi: Oxford University Press.

Chatterjee, Partha (2006) The Politics of the Governed: Reflections on Popular Politics in Most of the World, Delhi: Permanent Black.

Cole, Juan R.I. (1988) Roots of North Indian Shi' ism in Iran and Iraq: Religion and State in Awadh, 1722-1859, Berkeley: University of California Press.

Cole, Juan R.I. (2002) Sacred Space and Holy War: The Politics, Culture and History of Shi ite Islam, London: I.B. Tauris.

Daechsel, Markus (2005) The Politics of Self-Expression: the Urdu Middle-Class Milieu in Mid-Twentieth Century India and Pakistan, Abingdon: Routledge.

Devji, Faisal (2007) ‘Apologetic Modernity’, Modern Intellectual History 4(1), pp. 61-76.

Ebstein, Michael (2011) ‘Covenant (religious) pre-eternal', Encyclopaedia of Islam, $3^{\text {rd }}$ ed., Brill Online.

Fisher, Michael (1997) ‘Awadh and the English East India Company’, in Violette Graff (ed.), Lucknow: Memories of a City, Delhi: Oxford University Press.

Gaborieau, Marc (2011) “Abd al-Hayy Hasani', Encyclopaedia of Islam, $3^{\text {rd }}$ ed., Brill Online.

Gandhi, Mohandas Karamchand (1997 [1909]) Hind Swaraj, introduced and edited by Anthony Parel, Cambridge: Cambridge University Press.

Al-Ghazali, Abu Hamid Muhammad ibn Muhammad (1995 [1095-1106]) Kitāb Riyādat al-Nafs waTahdhïb al-Akhlāq va-Mu'ālajat Amrād al-Qalb (On Disciplining the Soul, Refining the Character and 
Curing the Sickness of Hearts), translated and introduced by Tim Winter, Cambridge: Islamic Texts Society.

Gilmartin, David and Lawrence, Bruce (eds.) (2000) Beyond Turk and Hindu: Rethinking Religious Identities in Islamicate South Asia, Gainesville: University of Florida Press.

Geertz, Clifford (1971) Islam Observed: Religious Development in Morocco and Indonesia, Chicago: University of Chicago Press.

Graff, Violette (ed.) (1997) Lucknow: Memories of a City, Delhi: Oxford University Press.

Gupta, Charu (2005) Sexuality, Obscenity, Community: Women, Muslims and the Hindu Public in Colonial India, Delhi: Permanent Black.

Hali, Altaf Husain (1998 [1879]) Musaddas: The Ebb and Flow of Islam, introduced by Christopher Shackle and Javed Majeed, Delhi: Oxford University Press.

Hasan, Mushirul (2007a) A Moral Reckoning: Muslim Intellectuals in Nineteenth-Century Delhi, Delhi: Oxford University Press.

Al-Hasani, ‘Abd al-Ha'i (n.d. [1910s]) Tehzïb al-Akhlāq, Lucknow: Dar-ul-Asha'at-i-Nadwa’t ul-'Ulama.

Haynes, Douglas (1991) Rhetoric and Ritual: The Shaping of a Public Culture in Surat City, 1852-1928, Berkeley: University of California Press.

Hindi, Sayyid Ahmad (2010 [1918]) Warāthat ul-Anbìya, Qom: Moussa Kitab Shinasi-i-Shi'ah.

Hodgson, Marshall (1974) The Venture of Islam: Conscience and History in a World Civilization, Vol I, Chicago: University of Chicago Press.

Husain, Mirza Habib (1900) Ma'adin-i-Tehzib, Lucknow: Nawal Kishore Press.

Husain, Mirza Ja‘far (1981) Qādìm Lakhna’u kī Akhirī Bahar, Delhi: Anjuman-i-Taraqqi-i-Urdu.

Husain, Mirza Muhammad Ja'far (c.1943) Rapōrt-i-Luckna'u Husēn Dēy Kamitī, mukamil rūì̀ād-ijalsa-i-hā'ì sēzdah sad-sāla-i-Yādgār-i-Husēnī, munaqīda 16-18 Āgust 1942, Lucknow.

Iqbal, Muhammad (1993 [1932]) 'The Mosque of Cordoba', in David Matthews (ed.), Iqbal, Urdu verse, London: School of Oriental and African Studies, pp. 96-107.

Jones, Justin (2012) Shi' a Islam in Colonial India: Religion, Community and Sectarianism, Cambridge, Cambridge University Press.

Jones, Justin (2014) 'Shi' ism, Humanity and Revolution in Twentieth Century India: Selfhood and Politics in the Husainology of 'Ali Naqi Naqvi', Journal of the Royal Asiatic Society, 24(3), pp. 415-34.

Joshi, Sanjay (2001) Fractured Modernity: Making of a Middle Class in Colonial North India, Delhi: Oxford University Press.

Khan, Ihsan ‘Ali (1878) Tehzīb-i-Ihsānī, Lucknow: Nawal Kishore Press.

Khan, Syed Ahmad (1861) Description des Monuments de Dehli en 1852, d'Après le Texte Hindoustani de Saiyid Ahmad Khan, translated by Garcin de Tassy, Paris: Extrait du Journal Asiatique.

Kidambi, Prashant (2012) 'Nationalism and the City in Colonial India: Bombay, c.1890-1940', Journal of Urban History, 38(5), pp. 950-967.

Kidwai, R.R. (1993) Lucknow: the Lost Paradise, Lucknow: S.R. Publications.

Kudaisya, Gyanesh (2007) “'Aryavarta,' 'Hind,' or 'Uttar Pradesh': The Postcolonial Naming and Framing of a 'Region', in Dipesh Chakrabarty, Rochona Majumdar and Andrew Sartori (eds.), From the Colonial to the Postcolonial: India and Pakistan in Transition, Delhi: Oxford University Press. 
Llewellyn-Jones, Rosie (1997) 'Lucknow, City of Dreams', in Violette Graff (ed.), Lucknow: Memories of a City, Delhi: Oxford University Press, pp. 49-66.

Lucknowi, Syed Muhammad Hadi (1912) Wa`zdārān-i-Luckna’u, Lucknow: Nawal Kishore Press.

March, Andrew (2009) 'Sources of Moral Obligation to non-Muslims in the Jurisprudence of Muslim Minorities (Fiqh al-aqalliyyat) Discourse', Islamic Law and Society, 16 (2009), pp.34-94.

Ibn Miskawayh, Ahmad ibn Muhammad (2002-3) Tadhïb al-Akhlāq va-tathīr al-árāq, translated and introduced by 'Ali Asghar Halabi, Tehran: Asatir.

Nadvi, Abul Hasan 'Ali (1960) Muslims in India (al Muslimūn fï al-Hind), Lucknow: Academy of Islamic Research and Publications.

Naim, C.M. (2011) 'Interrogating ‘The East', 'Culture' and 'Loss' in Abdul Halim Sharar's Guzashta Lakhna'u', in Alka Patel and Karen Leonard (eds.), Indo-Muslim cultures in transition, Leiden: Brill, pp. 189-204.

Nu'mani, Shibli (1993 [1890s]) 'Hindūstān mēin Islāmī Hukūmat kē Tamaddun kā asr', republished in Rashid Hasan Khan (ed.), Intikhāb-i-Muzāmīn-i-Shiblī, Delhi: Maktaba-i-Jami'ya Limited.

Oldenburg, Veena Talwar (1984) The Making of Colonial Lucknow: 1856-1877, New Jersey: Princeton University Press.

Oldenburg, Veena Talwar (1997) 'Lifestyle as Resistance: the Case of the Courtesans of Lucknow' in Violette Graff (ed.), Lucknow: Memories of a City, Delhi: Oxford University Press, pp. 136-54.

Oldenburg, Veena Talwar (ed.) (2007) Shaam-e-Awadh: writings on Lucknow, Mumbai: Penguin Books India.

Opwis, Felicitas (2005) 'Maslaha in Contemporary Islamic Legal Theory', Islamic Law and Society, 12 (2), pp. 182-223.

Owen, Hugh (1972) 'Negotiating the Lucknow Pact', Journal of Asian Studies, 31(3), pp. 561-87.

Perkins, Christopher Ryan (2011) 'Partitioning History: the Creation of an Islāmī Pablik in Late Colonial India, c.1880-1920', Unpublished PhD thesis, University of Pennsylvania.

Perkins, Christopher Ryan (2013) 'From the Mehfil to the Printed Word: Public Debate and Discourse in Late Colonial India', The Indian Economic and Social History Review, 50(1), pp. 47-76.

Prakash, Gyan (2010) Mumbai Fables: a History of an Enchanted City, Princeton: Princeton University Press.

Premchand, Munshi (2007 [1924]) 'Shatranj ke Khelari', republished in Veena Talwar Oldenburg (ed.), Shaam-e-Awadh: writings on Lucknow, Mumbai: Penguin Books India.

Rampuri, Najmul Ghani (1919) Tārīkh-i-Awadh, Jald-i-Chārhūm, Lucknow: Nawal Kishore Press.

Reid, Anthony (2008) 'Introduction: Muslims and Power in a Plural Asia', in Michael Gilsenan \& Anthony Reid (eds.), Islamic Legitimacy in a Plural Asia, Abingdon: Routledge, pp. 1-13.

Robinson, Francis (1974) Separatism Among Indian Muslims: the Politics of the United Provinces' Muslims, 1860-1923, Cambridge: Cambridge University Press.

Robinson, Francis (1997) 'The Re-emergence of Lucknow as a Major Political Centre, 1899-early 1920s' in Violette Graff (ed.), Lucknow: Memories of a City, Delhi: Oxford University Press, pp. 196-212.

Ruswa, Mirza Muhammad Hadi (1993 [1899]) Umrao Jan Ada, translated and introduced by Khushwant Singh and M.A. Husaini, Delhi: Orient Blackswan. 
Sharar, Abdul Halim (2000 [1914-1920]) Hindūstān mēn Mashriqī Tamaddun kā Akhirī Namūna ya ni Guzushta Luckna'u, New Delhi: Maktaba Jami‘a Millia.

Sharar, Abdul Halim (1975) Lucknow: The Last Phase of an Oriental Culture, translated and edited by E.S. Harcourt and Fakhir Hussain, Delhi: Oxford University Press.

Sikand (2000) Muslims in India Since 1947: Islamic Perspectives on Inter-faith Relations, London: RoutledgeCurzon.

Simpson, Edward and Kresse, Kai (2007) 'Cosmopolitanism Contested: Anthropology and History in the Western Indian Ocean', in Edward Simpson and Kai Kresse (eds.), Struggling with History: Islam and Cosmopolitanism in the Western Indian Ocean, London: Hurst Publishers, pp. 1-42.

Stark, Ulrike (2007) An Empire of Books: the Nawal Kishore Press and the Diffusion of the Printed Word in Colonial India, Delhi: Permanent Black.

Stark, Ulrike (2011) 'Associational Culture and Civic Engagement in Colonial Lucknow: the Jalsahe Tahzib', Indian Economic and Social History Review, 48(1), pp. 1-33.

Thomas, David (1982) 'Lucknow and Kanpur 1880-1920: Stagnation and Development Under the Raj, South Asia: Journal of South Asian Studies, 5(2), pp. 68-80.

Varshney, Ashutosh (2003) Ethnic Conflict and Civic Life: Hindus and Muslims in India, New Haven: Yale University Press.

Watt, Carey (2005) Serving the Nation: Cultures of Service, Association and Citizenship in Colonial India, Delhi: Oxford University Press.

Zaidi, Akbar (2009) 'Contested Identities and the Muslim Qaum in Northern India, c.1860-1900', Unpublished PhD thesis, University of Cambridge.

\section{NOTES}

1. Recent studies of "Abdul Halim Sharar and his work include Naim (2011) and, especially, Perkins (2011), which provides the fullest and most sophisticated treatment of the subject to date.

2. I borrow this term from Marshall Hodgson, who famously used it to 'refer not directly to the religion, Islam, itself, but to the social and cultural complex historically associated with Islam... both among Muslims themselves and even when found among non-Muslims' (Hodgson 1974: 57-59). It has been widely elaborated in studies of South Asian Islam, e.g. Gilmartin \& Lawrence (eds.) (2000).

3. For instance, to describe Unani medical sciences in a text by a city hakim (physician): (Ihsani 1878).

4. The influential reformist and historian Shibli Nu'mani used the phrase to describe the administrative and technological developments brought to India by Jehangir (Nu'mani 1993 [1890s]: 321-4).

5. The Leader (Allahabad), 21 April 1911, Centre of South Asian Studies, Cambridge.

6. All India Shi'a Gazette (Lucknow), 21 April 1911; Tafrih (Lucknow) 21 April 1911; Mashriq (Gorakhpur) 18 April 1911; Advocate (Lucknow) 30 April 1911; Zamindar-va-Kashtkar (Bijnor), May 1911, Awadh Akhbar (Lucknow) 5 August 1911, United Provinces Native Newspaper Reports (UPNNR), British Library.

7. These details are taken from: Ambika Bazaar Patrika (Calcutta), 1-3 January 1917, British Library; Hindustani (Lucknow), 21 January 1917 and Mashriq (Gorakhpur) 23 January 1917, UPNNR; Ambedkar 1946: 141; Owen 1972: 561; Robinson 1997:207-8. 
8. These include the Arabic hadis collection Tehzib-ul-Akhlāq compiled by 'Abdul Ha'i al-Hasani, one of Nadva't ul-'Ulama's most significant formative-era scholars (al-Hasani n.d. [1910s]; Stark 2011:5; Gaborieau 2011), and Ahmad (2005[1920]), a translation and commentary of a collection of Shi'i hadis compiled in Safavid Iran.

9. See this description of late Mughal Delhi by one nationalist campaigner: 'the two communities, Hindu and Musalman, had come to live peaceably side by side under the wise guidance of the Moghul emperors... this general contentment had been a growth of centuries; and the Moghul Emperors... deserve credit for the manner in which they had overcome within themselves bigotry and prejudice, and...were able to treat their Hindu subjects with kindly consideration' (Andrews 2003 [1929]: 27). Andrews's account bears comparison with Sharar's work in various ways: its basis in oral testimonies from Muslim residents; its nostalgic tone; its location of communal unity in pre-colonial civility; and, significantly, its implied grounding of pluralism and tolerance within Islam.

10. Gandhi described India's major cities as India's 'plague spots', as 'a matter for sorrow' and 'a snare and useless encumbrance', in contrast with much-lauded 'village India' (Gandhi 1997 [1909]: 69). Similarly Babylonian ideas of the city as source of degradation populated the thought of many anti-colonial and anti-Western thinkers globally during this period (Buruma \& Margalit 2004: 13-48).

\section{ABSTRACTS}

Many frameworks for the writing of urban history in South Asia have interpreted the city as a space of socio-political organisation, rather than an object of thought itself. By contrast, this article examines how a mythologised version of Lucknow's illustrious pre-colonial history, particularly its supposed cultural refinement (tehzib), was evoked in the colonial-era city. Examining the remembrance of old Lucknow in print and public life, this article argues that this historical mythology was at points harnessed for many contemporary purposes, including offering respite from a hostile present, providing a model for Hindu-Muslim political concord, and articulating a distinctively Islamic interpretation of modern religious pluralism.

INDEX

Keywords: Lucknow, tehzib, mythology, urban history, public sphere, Islam, cosmopolitanism

\section{AUTHOR}

JUSTIN JONES

University of Oxford 